\title{
Clomiphene Citrate Induces ROS-Mediated Apoptosis in Mammalian Oocytes
}

\author{
Shail K. Chaube1*, Tulsidas G. Shrivastav², Shilpa Prasad1, Meenakshi Tiwari1, \\ Anima Tripathi ${ }^{1}$, Ashutosh N. Pandey ${ }^{1}$, Karuppanan V. Premkumar ${ }^{1}$ \\ ${ }^{1}$ Cell Physiology Laboratory, Biochemistry Unit, Department of Zoology, Banaras Hindu University, \\ Varanasi-221005, India \\ ${ }^{2}$ Department of Reproductive Biomedicine, National Institute of Health and Family Welfare, New Delhi-110067, \\ India \\ Email: shailchaubey@gmail.com
}

Received 27 May 2014; revised 28 June 2014; accepted 16 July 2014

Copyright (C) 2014 by authors and Scientific Research Publishing Inc.

This work is licensed under the Creative Commons Attribution International License (CC BY).

http://creativecommons.org/licenses/by/4.0/

(c) (i) Open Access

\section{Abstract}

The clomiphene citrate (CC), a nonsteroidal triphenylethylene compound, is a first line of medicine used for the induction of ovulation in anovulatory women worldwide. In spite of high ovulation induction with the use of CC, the pregnancy rate is much lower. Such a discrepancy could be due to the peripheral anti-estrogenic effect of CC, particularly at the level of ovary, endometrium and cervical mucus. CC induces ovulation by binding to the estrogen receptors and generates hypoestrogrnic state in hypothalamus leading to release of pituitary gonadotropins. CC may have a direct effect at the level of ovary but the molecular mechanism remains unclear. Animal studies suggest that the CC induces apoptosis in granulosa cells and results hypoestrogenic state in the ovary. Reduced estradiol $17 \beta$ level in the ovary affects development and maturation of oocyte leading to oocyte apoptosis. Further, $\mathrm{CC}$ increases hydrogen peroxide $\left(\mathrm{H}_{2} \mathrm{O}_{2}\right)$ level and thereby bax protein expression and DNA fragmentation in cumulus-granulosa cells as well as in oocytes. The exogenous supplementation of either estradiol $17 \beta$ or melatonin reduces $\mathrm{H}_{2} \mathrm{O}_{2}$ level in ovary, delays meiotic cell cycle progression in oocyte and protects oocyte apoptosis. Hence, supplementation of estradiol $17 \beta$ or melatonin along with $C C$ could be beneficial to protect granulosa cell as well as oocyte apoptosis and inhibit deterioration of oocyte quality. Thus, maintenance of oocyte quality may overcome the adverse effect caused due to $\mathrm{CC}$ treatment during infertility management.

\section{Keywords}

Clomiphene Citrate, Ovulation Induction, ROS Generation, Apoptosis, Oocyte Quality

"Corresponding author. 


\section{Introduction}

Ovary is a metabolically active organ that generates reactive oxygen species (ROS) on an extraordinary scale during final stages of folliculogenesis and ovulation. These increased levels of ROS are scavenged by enzymatic as well as non-enzymatic antioxidants [1]-[3]. Although generation of a tonic level of ROS is beneficial for meiotic maturation in rat oocytes [4]-[6], overproduction of ROS in the follicular fluid or depletion of antioxidant system leads to oxidative stress [1] that may affect oocyte quality and thereby ART outcome [7].

Ovulatory dysfunction is one of the most common causes of reproductive failure in sub-fertile and infertile women. The anovulatory infertility may be because of polycystic ovary syndrome (PCOS), obesity, hypothalamic dysfunction, stress, hyperprolactinemia, pituitary tumors or thyroid disease in human [8]. The unexplained infertility contributes to $20 \%$ - $25 \%$ of total infertility in female [9]. In the absence of other significant infertility factors in couples, successful ovulation induction often restores normal fertility in human [10].

The injectable gonadotropins or anti-estrogens including clomiphene citrate (CC) is used to stimulate ovary in infertile women [11]. Gonadotropin induces steroidogenesis in follicular cells by cyclic adenosine 3',5'-cyclic monophosphate (cAMP)-mediated pathway and stimulates growth, development and maturation of mammalian ovarian follicles [12]-[14]. Further, studies in monkey as well as in cattle suggest that gonadotropins directly stimulate PGE2 synthesis in granulosa cells required for follicular rupture that results in ovulation [15]-[17]. However, exogenous gonadotropin therapy is an expensive treatment and also requires clinicians with requisite training and experience. CC is a very cheap and easily available drug and hence it is poor man's medicine for the treatment of anovulatory dysfunction worldwide. More than $80 \%$ of women ovulate when they are treated with CC [9].

CC is a synthetic compound composed of two isomers, enclomiphine and zuclomiphine [18] approximately in a ratio of 3:2 [9]. Chemically, CC is a nonsteroidal triphenylethylene derivative that exhibits both estrogen agonist and antagonist properties [19]. Estrogen agonist properties are seen only if the endogenous estrogen level is extremely low. Otherwise, CC acts as a competitive estrogen antagonist. Approximately 85\% of an administered dose is eliminated after approximately 6 days, although traces may remain in the circulation for much longer [20]. Available evidence indicates that enclomiphene is the more potent isomer and the one primarily responsible for the ovulation-inducing actions of CC [19] [21]. Enclomiphene levels rise rapidly after administration and fall to undetectable concentrations soon thereafter. Zuclomiphene is a less active isomer; it is cleared far more slowly [22].

\section{Mechanism of Action of Clomiphene Citrate during Ovulation Induction in Human}

CC is the first line of medicine used for ovulation induction in anovulatory women worldwide [9]. CC is structurally similar to estrogen and thus it binds to estrogen receptors (ER) at the hypothalamic level as depletion of hypothalamic ER prevents correct analysis of circulating estrogen levels. Feedback due to this reduced estrogen level triggers hypothalamic gonadotropin-releasing hormone (GnRH) secretion. The increased GnRH secretion from hypothalamus stimulates the release of pituitary gonadotropins. Both luteinizing hormone (LH) as well as follicle stimulating hormone (FSH) surge finally triggers growth and development of ovarian follicles by inducing steroidogenesis [23]. In successful treatment cycle with CC one or more dominant follicle emerge, mature and finally gets ruptured that results in the ovulation of M-II arrested oocytes required for successful fertilization in various ART programs. However, CC treatment may be ineffective in women with hypogonadotropic hypogonadism as well as hypergonadotropic hypogonadism [9]. Although standard effective dose of CC ranges from $50 \mathrm{mg}$ per day-250 mg per day, more than $100 \mathrm{mg}$ per day is not permitted by US Food and Drug Administration [24]. The CC dose is increased from $50 \mathrm{mg}$ to $100 \mathrm{mg}$ and even more in patients who do not ovulate at standard effective dose of CC. However, ovulation rate decreases with the increasing dose of CC (22\% with 100 mg, $12 \%$ with $150 \mathrm{mg}$, 7\% with $200 \mathrm{mg}$ and 5\% with $250 \mathrm{mg}$ per day) [25]. Higher doses of CC may trigger ovarian hyperstimulation and granulosa cell apoptosis in vitro. Clinically, multiple gestation, congenital anomalies and ovarian cancer occur with high dose of CC treatment [9] [26]. Although, CC has been used for ovulation induction worldwide, the possible molecular mechanisms of how CC works at the level of ovary remains ill understood.

\section{Clomiphene Citrate-Induced Apoptosis}

In spite of high ovulation induction with the use of CC (57\% - 91\%), the pregnancy rate (20\% - 40\%) is much 
lower in humans [27]. Moreover, there is a higher than expected incidence of miscarriage in the conception cycle after CC treatment in humans [28]. Such a discrepancy is believed to be due to anti-estrogenic effect of CC, particularly at the level of ovary, cervical mucus and endometrium in human [25] [29]-[31]. The anti-estrogenic effects of CC may affect final stages of folliculogenesis by inducing apoptosis in encircling granulosa cells and oocyte in ovary in vitro. This was further strengthened by animal studies that CC treatment induced granulosa cell as well as oocyte apoptosis in rats in vivo [32]. However, there is no evidence to support this possibility in human.

The anti-estrogenic effects of CC and the mechanism by which CC exerts its direct action at the level of ovary remains poorly understood. One study suggest that CC induces apoptosis in human granulosa cells cultured in vitro [26] and reduces estradiol $17 \beta$ as well as progesterone synthesis in rat [33] and in humans [26] [34]. These finding were further supported by animal studies that CC induces granulosa cell apoptosis and reduced level of estradiol $17 \beta$ in ovary as well as circulation in rat [32] [35] as well as in monkey [36]. Studies carried out in humans as well as in animal model suggest that CC induces granulosa cell apoptosis, which are the main source of estradiol $17 \beta$ biosynthesis. The decreased number of the active granulosa cells could be one of the causes for the reduction of estradiol $17 \beta$ level in ovary as well as circulation.

The developed hypoestrogenic condition after CC treatment may induce generation of ROS and thereby deterioration of oocyte quality by inducing apoptosis. This possibility was further strengthened by observations that CC treatment increased hydrogen peroxide $\left(\mathrm{H}_{2} \mathrm{O}_{2}\right)$ level and reduced catalase activity in ovary. The increased level of $\mathrm{H}_{2} \mathrm{O}_{2}$ induced bax protein expression and DNA fragmentation both in cumulus-granulosa cells and oocytes in rat as well as in human [32] [35]. Further, CC induced atretic like changes in preovulatory follicles [37], induced oocyte degeneration and reduced fertilization [38] [39]. Based on these studies, we propose that CC induces generation of ROS and thereby apoptosis in granulosa cells. Granulosa cell apoptosis further reduces estradiol $17 \beta$ level in ovary as well as in circulation. The reduced level of estradiol $17 \beta$ in ovary may affect the achievement of meiotic competency of follicular oocytes. After ovulation, these oocytes become more susceptible towards apoptosis, which results in the deterioration of oocyte quality and poor assisted reproductive technology (ART) outcome.

\section{Protection of Clomiphene Citrate-Induced Apoptosis}

The hypoestrogenic condition due to CC treatment affects the development and maturation of oocytes in the ovary and reduces oocyte quality after ovulation. The increased estradiol $17 \beta$ even at supraphysiological level (3000 pg/mL of serum) does not affect the oocyte and embryo quality in the oocyte donation cycle of human [40]. Hence, a possibility exists that the exogenous supplementation of estradiol $17 \beta$ may prevent CC-induced hypoestrogenic condition. This possibility was further supported by data obtained through animal studies in rat model that the exogenous supplementation of estradiol $17 \beta$ compensates CC induced hypoestrogenic condition and maintains granulosa cell survival inside follicular microenvironment [33]. The increased growth and survival factor due to exogenous supplementation of estradiol $17 \beta$ protects deterioration of oocyte quality [32] [33]. The use of exogenous estradiol $17 \beta$ has been recommended after the completion of CC regimen in humans, and clinical studies have supported the beneficial effects of exogenous estradiol $17 \beta$ in patients [41]-[45]. Hence, the use of exogenous estradiol $17 \beta$ can overcomes the side effects of CC during ovulation induction in humans (Figure 1).

CC induces generation of ROS and apoptosis in cancer cells [46]. Animal studies suggest that CC induces accumulation of ROS in ovary possibly by inhibiting catalase activity leading to oocyte apoptosis in rat [35]. Therefore, the use of natural antioxidant could be better over estradiol $17 \beta$ supplementation in terms of preventing CC-induced adverse effects at the level of ovary. Melatonin is a natural antioxidant which scavenges free radicals [47] and also induces antioxidant enzymes such as superoxide dismutase [48] [49] and glutathion peroxidase activities preventing oxidative damage in human [50] [51]. Previous studies suggest that melatonin supplementation protects oocytes from free radical damage, improving fertilization rate in rat, goat, porcine, ewes, ovine and human [7] [52]-[57] and inducing embryo viability in ewes [58]. Recently, it has been reported in rat oocytes that melatonin reduces $\mathrm{H}_{2} \mathrm{O}_{2}$ level by increasing catalase activity and protects against CC-induced oocyte apoptosis [35]. Further, melatonin slows down meiotic cell cycle progression since antral follicles had germinal vesicle stage oocytes and extrusion of first polar body was still in progress even after ovulation [35]. Thus, supplementation of melatonin could be beneficial to protect CC-induced generation of ROS and thereby 


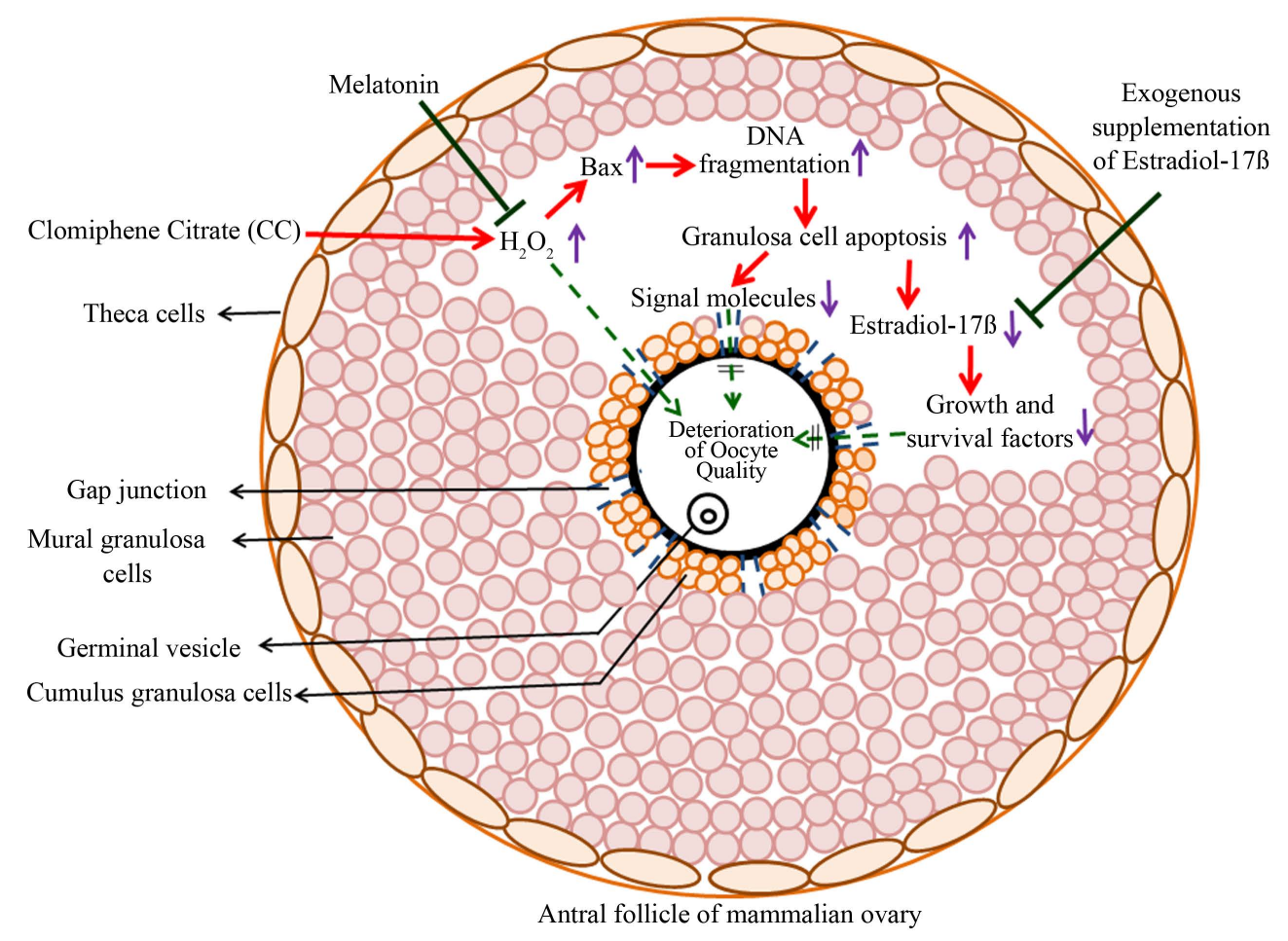

Figure 1. A schematic diagram showing the mechanism of CC action at ovarian antral follicle in mammals. CC induces generation of ROS and thereby granulosa cell apoptosis leading to disruption of cell communication and reduction of estradiol $17 \beta$ level in ovary. As a result, meiotic competency of oocyte is affected leading to oocyte apoptosis. Oocyte apoptosis deteriorates oocytes quality and directly affects fertilization as well as pregnancy rate resulting in poor reproductive outcome. Further, supplementation of estradiol $17 \beta$ or melatonin could be beneficial to overcome the adverse effects caused by CC treatment during infertility management in human.

apoptosis in mammalian ovary (Figure 1).

\section{Summary}

The molecular mechanism by which CC induces apoptosis at the level of ovary remains poorly understood in human. Based on the animal studies, we propose that CC induces generation of ROS and thereby apoptosis in granulosa cells that are responsible for estradiol $17 \beta$ synthesis. The granulosa cell apoptosis also reduces granulosa cells-oocyte communication by disrupting gap junctions. The disruption of gap junction affects the supply of nutrients and maturation enabling factors that are required for the achievement of meiotic competency of preovulatory oocytes. As a result, oocyte becomes more susceptible towards apoptosis that leads to deterioration of oocyte quality after ovulation leading to poor ART outcome. Thus, based on the animal studies, we suggest the use of either estradiol $17 \beta$ or melatonin along with CC to overcome the discrepancies rises due to adverse effects caused by CC at the level of ovary during infertility management in human.

\section{Conflict of Interest}

The authors declare no conflict of interest.

\section{References}

[1] Agarwal, A., Gupta, S. and Sharma, R. (2005) Oxidative Stress and Its Implications in Female Infertility-A Clinician's Perspective. Reproduction Biomedicine Online, 11, 641-650. http://dx.doi.org/10.1016/S1472-6483(10)61174-1

[2] Fujii, J., Iuchi, Y. and Okada, F. (2005) Fundamental Role of Reactive Oxygen Species and Protective Mechanism in the Female Reproductive Systems. Reproduction Biology and Endocrinology, 3, 43-52. http://dx.doi.org/10.1186/1477-7827-3-43 
[3] Sugino, N. (2005) Reactive Oxygen Species in Ovarian Physiology. Reproductive Medicine and Biology, 4, 31-44. http://dx.doi.org/10.1007/BF03016135

[4] Chaube, S.K., Khatun, S., Misra, S.K. and Shrivastav, T.G. (2008) Calcium Ionophore-Induced Egg Activation and Apoptosis Are Associated with the Generation of Intracellular Hydrogen Peroxide. Free Radical Research, 42, 212220. http://dx.doi.org/10.1080/10715760701868352

[5] Tripathi, A., Khatun, S., Pandey, A.N., Mishra, S.K., Chaube, R., Shrivastava, T.G. and Chaube, S.K. (2009) Intracellular Levels of Hydrogen Peroxide and Nitric Oxide in Oocyte at Various Stages of Meiotic Cell Cycle and Apoptosis. Free Radical Research, 43, 287-294. http://dx.doi.org/10.1080/10715760802695985

[6] Tripathi, A., Kumar, K.V.P. and Chaube, S.K. (2010) Meiotic Cell Cycle Arrest in Mammalian Oocytes. Journal of Cellular Physiology, 223, 592-600.

[7] Tamura, H., Takasaki, A., Miwa, I., Taniguchi, K., Maekawa, R., Asada, H., Taketani, T., Matsuoka, A., Yamagata, Y., Shimamura, K., Morioka, H., Ishikawa, H., Reiter, R.J. and Sugino, N. (2008) Oxidative Stress Impairs Oocyte Quality and Melatonin Protects Oocytes from Free Radical Damage and Improves Fertilization Rate. Journal of Pineal Research, 44, 280-287. http://dx.doi.org/10.1111/j.1600-079X.2007.00524.X

[8] Tripathy, S., Mohapatra, S., Muthulakshmi, M. and Chandrasekhar, A. (2013) Induction of Ovulation with Clomiphine citrate Versus Clomiphene with Bromocriptine in PCOS Patients with Normal Prolactin: A Comparative Study. Journal of Clinical and Diagnostic Research, 7, 2541-2543.

[9] Practice Committee of the American Society of Reproductive Medicine (2013) Use of Clomiphine Citrate in Infertile Women: A Committee Opinion. Fertility Sterility, 100, 341-348. http://dx.doi.org/10.1016/j.fertnstert.2013.05.033

[10] Practice Committee of the American Society for Reproductive Medicine (2003) Use of Clomiphene Citrate in Women. Fertility Sterility, 80, 1302-1308. http://dx.doi.org/10.1016/S0015-0282(03)01184-1

[11] Barbieri, R.L. (1999) Infertility. In: Yen, S.S.C., Jaffe, R.B. and Barbieri, R.L., Eds., Reproductive Endocrinology-Physiology, Pathophysiology, and Clinical Management, 4th Edition, WB Saunders, Philadelphia, 563-593.

[12] Wassarman, P.M. and Albertini, D.F. (1994). The Mammalian Ovum In: Knobil, E. and Neill, J.D., Eds., The physiology of Reproduction, Raven Press, New York, 79-122.

[13] Acosta, T.J., Miyamoto, A., Ozawa, T., Wijayagunawardane, M.P. and Sato, K. (1998) Local Release of Steroid Hormones, Prostaglandin E2, and Endothelin-1 from Bovine Mature Follicles in Vitro: Effects of Luteinizing Hormone, Endothelin-1 and Cytokines. Biology of Reproduction, 59, 437-443. http://dx.doi.org/10.1095/biolreprod59.2.437

[14] Chaube, S.K. (2001) Role of Meiotic Maturation Regulatory Factors in Developmental Competency of Mammalian oocytes. Health and Population Perspect Issues, 24, 218-231.

[15] Duffy, D.M. and Stouffer, R.L. (2003) Luteinizing Hormone Acts Directly at Granulose Cells to Stimulate Periovulatory Processes: Modulation of Luteinizing Hormone Effects by Prostaglandins. Endocrine, 22, 249-256. http://dx.doi.org/10.1385/ENDO:22:3:249

[16] Peters, M.W., Pursley, J.R. and Smith G.W. (2004) Inhibition of Intrafollicular PGE2 Synthesis And ovulation Following Ultrasound-Mediated Intrafollicular Injection of the Selective Cyclooxygenease-2 Inhibitor NS-398 in Cattle. Journal of Animal Science, 82, 1656-1662.

[17] Duffy, D.M., Dozier, B.L. and Seachord, C.L. (2005) Prostaglandin Dehydrogenase (PGDH) and Prostaglandin Levels in Preovulatory Follicles: Implications for Control of Primate Ovulation by PGE2. Journal of Clinical Endocrinology and Metabolism, 90, 1021-1027. http://dx.doi.org/10.1210/jc.2004-1229

[18] Homburg, R. (2005) Clomiphine Citrate: End of an Era? A Mini Review. Human Reproduction, 20, $2043-2051$. http://dx.doi.org/10.1093/humrep/dei042

[19] Clark, J.H. and Markaverich, B.M. (1981) The Agonist-Antagonistic Properties of Clomiphene: A Review. Pharmacology and Therapeutics, 15, 467-519. http://dx.doi.org/10.1016/0163-7258(81)90055-3

[20] Mikkelson, T.J., Kroboth, P.D., Cameron, W.J., Dittert, L.W., Chungi, V. and Manberg, P.J. (1986) Single-Dose Pharmacokinetics of Clomophine Citrate in Normal Volunteers. Fertility and Sterility, 46, 392-396.

[21] Van, C.J., Borreman, E., Wyman, H. and Antaki, A. (1973) Induction of ovulation with Cisclomiphine. American Journal of Obstetrics Gynecology, 115, 321-327.

[22] Young, S.L., Opsahl, M.S. and Fritz, M.A. (1999) Serum Concentrations of Enclomiphine and Zuclomiphine across Consecutive Cycles of Clomiphine Citrate Therapy in Anovulatory Infertile Woman. Fertility and Sterility, 71, 639-644. http://dx.doi.org/10.1016/S0015-0282(98)00537-8

[23] Reber, R., Judd, H.L., Yen, S.S.C., Rakoff, J., Vaden Berg, G. and Naftolin, F. (1976) Characterization of the Inappropriate Gonadotropin Secretion in Polycystic Ovary Syndrome. Journal of Clinical Investigation, 57, 1320-1329. http://dx.doi.org/10.1172/JCI108400

[24] Dodge, S.T., Strikler, R.C. and Keller, D.W. (1986) Ovulation Induction with Low Doses of Clomiphine Citrate. Ob- 
stetrics and Gynecology, 67, 635-655. http://dx.doi.org/10.1097/00006250-198603001-00019

[25] Gysler, M., March, C.M., Mishell Jr., D.R. and Bailey, E.J. (1982) A Decade’s Experience with an Individualized Clomiphine Treatment Regime Including IT's Effect on the Postcoital Test. Fertility and Sterility, 37, 161-167.

[26] Schwartz, L.B., Brezinski, A. and Laufer, N. (1993) The Effects of Clomiphene Citrate Isomers on Human GranulosaLutein Cells in Culture. Gynecological Endocrinology, 7, 229-233. http://dx.doi.org/10.3109/09513599309152506

[27] Mitwally, F.M. and Casper, R.F. (2002) Aromatase Inhibition for Ovarian Stimulation: Future Avenues for Infertility Management. Current Opinion in Obstetrics and Gynecology, 14, 255-263. http://dx.doi.org/10.1097/00001703-200206000-00003

[28] Goidfarb, M., Morales, A., Rakoff, A.E. and Portos, P. (1968) Critical Review of 160 Clomiphene-Related Pregnancies. Obstetrics and Gynecology, 31, 342-345. http://dx.doi.org/10.1097/00006250-196803000-00007

[29] Gonen, Y. and Casper, R.F. (1990) Sonographic Determination of a Possible Adverse Effect of Adverse Effect of Clomiphene Citrate on Endometrial Growth. Human Reproduction, 5, 670-674.

[30] Randall, J.M. and Templeton, A. (1991) Cervical Mucus Score and in Vitro Sperm Mucus Interaction in Spontaneous and Clomiphene Citrate Cycles. Fertility and Sterility, 56, 465-468.

[31] Li, T.C., Warren, M.A. and Murphy, C. (1999) A Prospective, Randomized, Cross-Over Study Comparing the Effects of Clomiphene Citrate and Cytophenil on Endometrial Morphology in the Luteal Phase of Normal Fertile Women. Fertility and Sterility, 71, 639-644.

[32] Chaube, S.K., Prasad, P.V., Thakur, S.C. and Srivastav, T.G. (2005) Estradiol Protects Clomiphene Citrate-Induced Apoptosis in Ovarian Follicular Cells and Ovulated Cumulus-Oocyte Complexes. Fertility and Sterility, 84, 11631172. http://dx.doi.org/10.1016/j.fertnstert.2005.03.073

[33] Chaube, S.K., Prasad, P.V., Tripathi, V. and Shrivastav, T.G. (2006) Clomiphene Citrate Inhibits Gonadotropin-Induced Ovulation by Reducing Cyclic Adenosine 3',5'-Cyclic Monophosphate and Prostaglandin $E_{2}$ Levels in Rat Ovary. Fertility and Sterility, 86, 1106-1111. http://dx.doi.org/10.1016/j.fertnstert.2006.03.027

[34] Olsson, J.H. and Granberg, S. (1990) Effect of Clomiphene Isomers on Oestradiol Synthesis in Cultured Human Granulosa Cells. Human Reproduction, 5, 928-932.

[35] Tripathi, A., Prem Kumar, K.V., Pandey, A.N., Khatun, S., Mishra, S.K., Shrivastava, T.G. and Chaube, S.K. (2011) Melatonin Protects against Clomiphine Citrate-Induced Generation of Hydrogen Peroxide and Morphological Apoptotic Changes in Rat Eggs. European Journal of Pharmacology, 667, 419-424. http://dx.doi.org/10.1016/j.ejphar.2011.06.005

[36] Marut, E.L. and Hodgen, G.D. (1982) Anti-Estrogenic Action of High-Dose Clomiphene in Primates: Pituitary Augmentation but with Ovarian Attenuation. Fertility and Sterility, 38, 100-104.

[37] Laufer, N., Reich, R., Braw, R., Shenker, J.G. and Tsafriri, A. (1982) Effect of Clomiphene Citrate on Preovulatory Rat Follicles in Culture. Biology of Reproduction, 27, 463-471. http://dx.doi.org/10.1095/biolreprod27.2.463

[38] Yashimura, Y., Hosoi, Y., Atlas, S.J. and Wallac, E. (1986) Effect of Clomiphene Citrate on in Vitro Ovulated Ova. Fertility and Sterility, 45, 800-804.

[39] Schmidt, G.E., Sites, C., Mansour, R., Friedman, C.I. and Kim, M.H. (1985) Embryo Toxicity of Clomiphene Citrate on Mouse Embryos Fertilized in Vitro and in Vivo. American Journal of Obstetrics Gynecology, 153, 679-684.

[40] Pena, J.E., Chang, P.L., Zeitoun, K., Thornton II, M.H. and Sauer, M.V. (2002) Supraphysiological Estradiol Levels Do Not Affect Oocyte and Embryo Quality in Oocyte Donation Cycles. Human Reproduction, 17, 83-87. http://dx.doi.org/10.1093/humrep/17.1.83

[41] Bateman, B.G., Nunley Jr., W.C. and Kolp, L.A. (1990) Exogenous Estrogen Therapy for Treatment of Clomiphene Citrate-Induced Cervical Mucus Abnormalities: Is It Effective? Fertility and Sterility, 54, 577-579.

[42] Yagel, S., Ben-Chetrit, A., Anteby, E., Zacut, D., Hochner-Celnikier, D. and Ron, M. (1992) The Effect of Ethinyl Estradiol on Endometrial Thickness and Uterine Volume during Ovulation Induction by Clomiphene Citrate. Fertility and Sterility, 57, 33-36.

[43] Ben-Ami, M., Geslevich, Y., Matilsky, M., Battino, S., Weiner, E. and Shlev, E. (1994) Exogenous Estrogen Therapy Concurrent with Clomiphene Citrate-Lack of Effect of Serum Sex Hormones Levels and Endometrial Thickness. Gynecologic and Obstetric Investigation, 37, 180-182.

[44] Shimoya, K., Tomiyama, K., Hashimoto, K., Moriyama, A., Kawamoto, A., Tokugawa, Y., Ohashi, K., Saji, F. and Murata, Y. (1999) Endometrial Development Was Improved by Transdermal Estradiol in Patients Treated with Clomiphene Citrate. Gynecologic and Obstetric Investigation, 47, 251-254. http://dx.doi.org/10.1159/000010116

[45] Gerli, S., Gholami, H. and Manna, A. (2000) Use of Ethinyl Estradiol to Reverse the Anti-Estrogenic Effects of Clomiphene Citrate in Patients Undergoing Intrauterine Insemination: A Comparative, Randomized Study. Fertility and Sterility, 73, 85-89. http://dx.doi.org/10.1016/S0015-0282(99)00447-1 
[46] Hayon, T., Bvilansky, A., Oriev, L. and Nathan, I. (1999) Non-Steroidal Antiestrogens Induce Apoptosis in HL60 and MOLT3 Luekemic Cells: Involvement of Reactive Oxygen Radicals and Protein Kinase C. Anticancer Research, 19, 2089-2093.

[47] Tan, D.X., Manchester, L.C., Terron, M.P., Flores, L.J. and Reiter, R.J. (2007) One Molecule, Many Derivatives: A Never-Ending Interaction of Melatonin with Reactive Oxygen and Nitrogen Species? Journal of Pineal Research, 42, 28-42. http://dx.doi.org/10.1111/j.1600-079X.2006.00407.x

[48] Liu, F. and Ng, T.B. (2000) Effect of Pineal Indoles on Activities of the Antioxidant Defense Enzymes Superoxide Dismutase, Catalase, and Glutathione Reductase, and Levels of Reduced and Oxidized Glutathione in Rat Tissues. Biochemistry and Cell Biology, 78, 447-453.

[49] Ozturk, G., Coskun, S., Erbas, D. and Hasanoglu, E. (2000) The Effect of Melatonin on Liver Superoxide Dismutase Activity, Serum Nitrate and Thyroid Hormone Levels. Japanese Journal of Physiology, 50, 149-153. http://dx.doi.org/10.2170/jjphysiol.50.149

[50] Reiter, R.J., Tan, D.X., Manchester, L.C. and Qi, W. (2001) Biochemical Reactivity of Melatonin with Reactive Oxygen and Nitrogen Species: A Review of the Evidence. Cell Biochemistry and Biophysics, 34, 237-256.

[51] Reiter, R.J., Tan, D.X., Manchester, L.C., Paredes, S.D., Mayo, J.C. and Sainz, R.M. (2009) Melatonin and Reproduction Revisited. Biology of Reproduction, 81, 445-456. http://dx.doi.org/10.1095/biolreprod.108.075655.

[52] Feng, Z. and Zhang, J.T. (2005) Long-Term Melatonin or 17 $\beta$-Estradiol Supplementation Alleviates Oxidative Stress in Ovariectomized Adult Rats. Free Radical Biology and Medicine, 39, 195-204. http://dx.doi.org/10.1016/j.freeradbiomed.2005.03.007

[53] Berlinguer, F., Leoni, G.G., Succu, S., Spezzigu, A., Madeddu, M., Satta, V., Bebbere, D., Contreras-Solis, I., Gonzalez-Bulnes, A. and Naitana, S. (2009) Exogenous Melatonin Positively Influences Follicular Dynamics, Oocyte Developmental Competence and Blastocyst Output in a Goat Model. Journal of Pineal Research, 46, 383-391. http://dx.doi.org/10.1111/j.1600-079X.2009.00674.x.

[54] Kang, J.T., Koo, O.J., Kwon, D.K., Park, H.J., Jang, G., Kang, S.K. and Lee, B.C. (2009) Effects of Melatonin on in Vitro Maturation of Porcine Oocyte and Expression of Melatonin Receptor RNA in Cumulus and Granulosa Cells. Journal of Pineal Research, 46, 22-28. http://dx.doi.org/10.1111/j.1600-079X.2008.00602.x.

[55] Tsiligianni, T., Valasi, I., Cseh, S., Vainas, E., Faigl, V., Samartzi, F., Papanikolaou, T., Dovolou, E. and Amiridis, G.S. (2009) Effects of Melatonin Treatment on Follicular Development and Oocyte Quality in Chios Ewes-Short Communication. Acta Veterinaria Hungarica, 57, 331-335. http://dx.doi.org/10.1556/AVet.57.2009.2.13.

[56] Vazquez, M., Forcada, F., Casao, A., Abecia, J., Sosa, C. and Palacin, I. (2010) Under Nutrition and Exogenous Melatonin Can Affect the in Vitro Developmental Competence of Ovine Oocytes on a Seasonal Basis. Reproduction in Domestic Animals, 45, 677-684. http://dx.doi.org/10.1111/j.1439-0531.2008.01329.x.

[57] Adriaens, I., Smitz, J. and Jacquet, P. (2009) The Current Knowledge on Radiosensitivity of Ovarian Follicle Development Stages. Human Reproduction Update, 15, 359-377. http://dx.doi.org/10.1093/humupd/dmn063.

[58] Forcada, F., Abecia, J.A., Cebrian-Perez, J.A., Muino, T., Valares, J.A., Palacin, I. and Casao, A. (2006) The Effect of Melatonin Implants during the Seasonal Anestrous on Embryo Production after Superovulation in Aged High-Prolificacy Rasa Aragonesa Ewes. Theriogenology, 65, 356-365.

http://dx.doi.org/10.1016/j.theriogenology.2005.05.038 
Scientific Research Publishing (SCIRP) is one of the largest Open Access journal publishers. It is currently publishing more than 200 open access, online, peer-reviewed journals covering a wide range of academic disciplines. SCIRP serves the worldwide academic communities and contributes to the progress and application of science with its publication.

Other selected journals from SCIRP are listed as below. Submit your manuscript to us via either submit@scirp.org or Online Submission Portal.
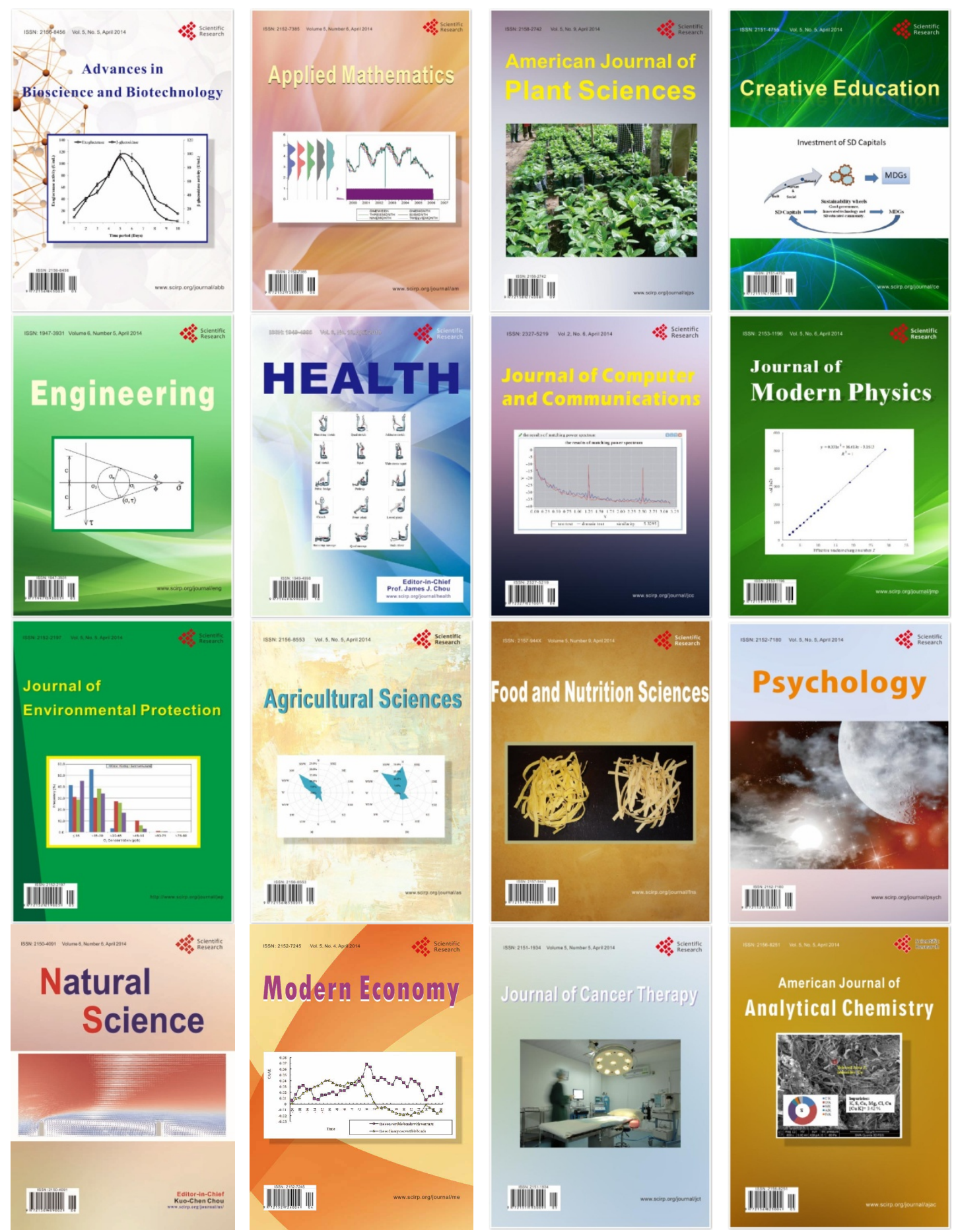